University of Nebraska - Lincoln

DigitalCommons@University of Nebraska - Lincoln

USDA National Wildlife Research Center - Staff Publications
U.S. Department of Agriculture: Animal and Plant Health Inspection Service

2018

\title{
Estimating Interspecific Economic Risk of Bird Strikes With Aircraft
}

Travis L. DeVault

USDA National Wildlife Research Center, Travis.L.DeVault@aphis.usda.gov

Bradley F. Blackwell

USDA National Wildlife Research Center, bradley.f.blackwell@aphis.usda.gov

Thomas W. Seamans

USDA National Wildlife Research Center, thomas.w.seamans@aphis.usda.gov

Michael J. Begier

USDA Airports Wildlife Hazards Program

Jason D. Kougher

USDA Airports Wildlife Hazards Program

See next page for additional authors

Follow this and additional works at: https://digitalcommons.unl.edu/icwdm_usdanwrc

Part of the Life Sciences Commons

DeVault, Travis L.; Blackwell, Bradley F.; Seamans, Thomas W.; Begier, Michael J.; Kougher, Jason D.; Washburn, Jenny E.; Miller, Phyllis R.; and Dolbeer, Richard A., "Estimating Interspecific Economic Risk of Bird Strikes With Aircraft" (2018). USDA National Wildlife Research Center - Staff Publications. 2074. https://digitalcommons.unl.edu/icwdm_usdanwrc/2074

This Article is brought to you for free and open access by the U.S. Department of Agriculture: Animal and Plant Health Inspection Service at DigitalCommons@University of Nebraska - Lincoln. It has been accepted for inclusion in USDA National Wildlife Research Center - Staff Publications by an authorized administrator of DigitalCommons@University of Nebraska - Lincoln. 


\section{Authors}

Travis L. DeVault, Bradley F. Blackwell, Thomas W. Seamans, Michael J. Begier, Jason D. Kougher, Jenny E. Washburn, Phyllis R. Miller, and Richard A. Dolbeer 
Original Article

\title{
Estimating Interspecific Economic Risk of Bird Strikes With Aircraft
}

TRAVIS L. DeVAULT, ${ }^{\mathbf{1}}$ U.S. Department of Agriculture, Animal and Plant Health Inspection Service, Wildife Services, National Wildlife Research Center, Obio Field Station, 6100 Columbus Avenue, Sandusky, OH 44870, USA

BRADLEY F. BLACKWELL, U.S. Department of Agriculture, Animal and Plant Health Inspection Service, Wildlife Services, National Wildlife Research Center, Obio Field Station, 6100 Columbus Avenue, Sandusky, OH 44870, USA

THOMAS W. SEAMANS, U.S. Department of Agriculture, Animal and Plant Health Inspection Service, Wildife Services, National Wildlife Research Center, Obio Field Station, 6100 Columbus Avenue, Sandusky, OH 44870, USA

MICHAEL J. BEGIER, U.S. Department of Agriculture, Animal and Plant Health Inspection Service, Wildlife Services, Airports Wildlife Hazards Program, 1400 Independence Avenue SW, Washington, D.C. 20250, USA

JASON D. KOUGHER, U.S. Department of Agriculture, Animal and Plant Health Inspection Service, Wildlife Services, Airports Wildlife Hazards Program, 6100 Columbus Avenue, Sandusky, OH 44870, USA

JENNY E. WASHBURN, U.S. Department of Agriculture, Animal and Plant Health Inspection Service, Wildlife Services, Airports Wildlife Hazards Program, 6100 Columbus Avenue, Sandusky, OH 44870, USA

PHYLLIS R. MILLER, U.S. Department of Agriculture, Animal and Plant Health Inspection Service, Wildife Services, Airports Wildlife Hazards Program, 6100 Columbus Avenue, Sandusky, OH 44870, USA

RICHARD A. DOLBEER, U.S. Department of Agriculture, Animal and Plant Health Inspection Service, Wildlife Services, Airports Wildlife Hazards Program, 6100 Columbus Avenue, Sandusky, OH 44870, USA

\begin{abstract}
The International Civil Aviation Organization promotes prioritization of wildlife management on airports, among other safety issues, by emphasizing the risk of wildlife-aircraft collisions (strikes). In its basic form, strike risk comprises a frequency component (i.e., how often strikes occur) and a severity component reflecting the cost of the incident. However, there is no widely accepted formula for estimating strike risk. Our goal was to develop a probabilistic risk metric that is adaptable for airports to use. Our specific objectives were to 1) update species-specific, relative hazard scores (i.e., the likelihood of aircraft damage or effect on flight when strikes occur) using recent U.S. Federal Aviation Administration (FAA) wildlife strike data (2010-2015); 2) develop 4 a priori risk models, reflecting species-specific strike data and updated relative hazard scores; 3 ) test these models against independent data (monetary costs associated with strikes); and 4) apply our best model to strike data from 4 large, FAA-certificated airports to illustrate its application at the local level. Our best-fitting risk model included an independent variable that was an interaction of quadratic transformed relative hazard score and number of wildlife strikes $\left(r^{2}=0.74\right)$. Top species in terms of estimated risk nationally were red-tailed hawk (Buteo jamaicensis), Canada goose (Branta canadensis), turkey vulture (Cathartes aura), rock pigeon (Columba livia), and mourning dove (Zenaida macroura). We found substantial overlap among the top 5 riskiest species locally across 3 of 4 airports considered, illustrating the degree of sitespecific differences that affect risk. Strike risk is dynamic; therefore, future work on risk estimation should allow for model adjustment to reflect ongoing wildlife management actions at airports that could influence future strike risk. Published 2018. This article is a U.S. Government work and is in the public domain in the USA.
\end{abstract}

KEY WORDS airport, aviation, bird strike, relative hazard score, strike risk.

Threats posed by wildlife to aviation safety have received growing recognition by the aviation community over the past 40 years (DeVault et al. 2013). Wildlife-aircraft collisions (strikes) primarily involve birds and result in costs to the civil aviation industry exceeding US $\$ 1.2$ billion annually (Allan 2002). These events pose safety hazards to passengers and crew, as well as people and structures on the ground (Dolbeer et al.

Received: 13 April 2017; Accepted: 24 November 2017

Published: 5 March 2018

${ }^{1}$ E-mail: travis.l.devault@aphis.usda.gov
2016). Wildlife management efforts on airports certificated for passenger traffic are now common in most developed countries. For example, the International Civil Aviation Organization (ICAO) recognizes the need to manage wildlife on member state airports (ICAO 2004). Guidance by ICAO and the U.S. Federal Aviation Administration (FAA) stresses minimization of food, water, and cover attractants to wildlife on and near airport property (ICAO 1991, 2002; FAA 2007a; Blackwell et al. 2009; Dolbeer 2013).

Although ICAO and FAA guidance serves to focus airport management on wildlife hazards, these suggestions are broad 
and, arguably, reactionary. In contrast, management based on estimated risk is intended to proactively direct management to mitigate immediate and future high-likelihood wildlife threats to aviation safety. Risk is a unitless metric comprising a conceptual understanding of the sources of the problem (e.g., particular species struck by aircraft, or factors contributing to wildlife hazards to aviation), realistic endpoints or potential events (e.g., a hull loss), mechanisms by which the sources contribute to the defined endpoints (e.g., a focused assessment of risk of engine failure upon ingestion of a bird), and a temporal or spatiotemporal estimate of exposure to the problem sources (Graham et al. 1991). Schafer et al. (2007) and Martin et al. (2011) advocated for the implementation of a risk assessment that reflects an index of species frequency within critical locations on and near the airport and associated strike-damage metrics or species-specific hazard scores (i.e., the likelihood of aircraft damage or effect on flight when strikes occur; DeVault et al. 2011; see also Soldatini et al. 2010, 2011). Blackwell et al. (2009) encouraged the development and maintenance of data sets accessible to airport planners and wildlife managers that would allow for a realistic assessment of strike risk relative to current airport conditions, as well as anticipated increases to airport capacity that would require modifications to habitats on and near airports. Moreover, under Annex 14, Volume 1, Aerodrome Design and Operations, ICAO (2004) introduced the requirement of Safety Management Systems for airports in member states (see also FAA 2007b, 2010; DeFusco et al. 2015), a program in which risk assessment is emphasized.

Several methods have been proposed to assess wildlife hazards to aviation (a component of a strike risk estimate) and manage those hazards on airports (DeVault et al. 2013), but progress toward a standardized and widely accepted strike-risk metric is in its early stages. Advances in estimation of strike risk (hereafter, risk) include metrics that allow airports to quantitatively compare their performance in mitigating strike hazards relative to other airports (e.g., Dolbeer and Wright 2009, Dolbeer and Begier 2012), and 2 primary approaches predominate. The first and most common approach incorporates an aspect of species-specific strike probability based on strike data reported over a period of years, combined with data on associated strike damage and negative effect on flight (e.g., the relative hazard scores proposed by Dolbeer et al. 2000 and DeVault et al. 2011). For instance, Allan (2006) developed a simple risk metric comprising an estimate of strike probability (based on a species-specific, 5-year rolling average of the number of strikes at an airport) and an associated severity index (percent of strikes involving a species that caused damage) derived from the UK Civil Aviation Authority Bird Strike Database. Dolbeer and Wright (2009) proposed a metric (termed a "benchmark" by the authors) for comparing adverse-effect strike rates among airports. The metric entails standardizing the number of damaging strikes per year by 100,000 aircraft movements (takeoff and landing $=2$ movements) and averaging that value over 5 years, thus reflecting a relative strike rate, but for only those strikes categorized as "damaging" (see Dolbeer et al. 2000 for definitions of aircraft damage resulting from strikes). More recently, Dolbeer and Begier (2012) applied the benchmark to strikes occurring $\leq 457 \mathrm{~m}$ (1,500 feet) above-ground-level (AGL), essentially within the airport airspace where wildlife management efforts would have a direct effect, and $>457 \mathrm{~m} \mathrm{AGL}$, thus outside the effects of airport wildlife management. Dolbeer and Begier (2012) noted that aircraft on approach and on a 3-degree glide slope are approximately $8 \mathrm{~km}$ from the runway at $457 \mathrm{~m}$ AGL, whereas aircraft on departure are closer to the airport when they climb through $457 \mathrm{~m}$. The FAA provides guidance for airports and surrounding communities relative to minimizing wildlife attractants within $8 \mathrm{~km}$ of an airport (14 CFR Part 139 §139.337). Importantly, however, only the metric proposed by Allan (2006) provides a relative probability of a negative outcome (in this case, damage to the aircraft) as a result of striking a particular species.

Soldatini et al. (2010, 2011) developed a risk metric for comparisons among airports, but modified the metric to assess airport-specific risk in greater detail. Specifically, their metric includes an airport-specific hazard component for a species-group - the Group Factor-based on mean mass, median flock size recorded on the airport, mean number of strikes per year standardized by total number of aircraft movements per year at the airport, and the highest ranking for species-group effect-on-flight for strikes incurred during that year. The authors then multiplied the Group Factor by the mean daily number of individuals for the species-group observed on the airport of interest for the specific month, yielding a species-group risk estimate. Notably, the survey component described by Soldatini et al. $(2010,2011)$ is intended as a standardized approach that will yield data relative to bird use of different airport land-cover types, but the metric relies on count data from a single survey point and does not account for biases in species and group abundances estimated during bird surveys (Blackwell et al. 2013).

In addition to the aforementioned quantitative risk metrics, the advent of Safety Management Systems has prompted development of more categorical approaches to defining strike risk, whereby strike data and hazard rankings are used, arguably in an arbitrary manner, and a specific risk metric is not defined (e.g., DeFusco et al. 2015). Within the context of a specific airport and assuming continuity in guidelines as to how biologists might transition from recording strikes and associated species-specific hazards to a risk category, the DeFusco et al. (2015) approach might work well. However, such categorical approaches do not lend themselves well to estimating risk in the form of a continuous probability, and inherently information is lost when species-specific metrics are categorized.

In summary, recent risk models either assume a stasis in risk that is reflected by strikes over the previous 5 years (Allan 2006), focus on across-airport comparisons of damaging strikes (Dolbeer and Begier 2012), attempt to quantify airport habitat contributions to strikes involving a speciesgroup (Soldatini et al. 2010,2011), or subjectively categorize risk (DeFusco et al. 2015). Although these proposed 
methods have contributed to the discussion on risk estimation techniques for wildlife strikes, only Soldatini et al. $(2010,2011)$ have attempted to validate risk estimates. However, their use of prior strike data from the same airport and current survey data in the validation brings into question the independence of the validation. Further, we note that the accuracy of the Soldatini et al. (2010, 2011) metric is dependent upon the quality of the survey data obtained. We therefore questioned whether a basic, species-specific strike-risk estimate might be developed that can be used as a foundation for directing management priorities that subsequently could be fine-tuned via survey data.

As such, our goal was to build upon these existing methods to develop a probabilistic risk metric that is adaptable for airport-specific analyses, and test the metric against independent data. For independent data, we used economic costs resulting from damaging strikes to evaluate 4 a priori models reflecting linear or quadratic relationships between risk and 2 independent factors that comprise the risk estimate: the number of strikes per species and hazard level (i.e., the likelihood of aircraft damage or effect on flight when strikes occur). Our specific objectives were to 1) update the relative hazard scores developed by Dolbeer et al. (2000) and DeVault et al. (2011) to incorporate FAA wildlife strike data from 2010 through 2015, a period that reflects an increase in reporting rate to $>90 \%$ (Dolbeer 2015); 2) develop a risk metric reflecting species-specific strike data and the updated relative hazard scores; 3) test the metric against independent strike-cost data; and 4) apply our metric to strike data from 4 large, FAA-certificated airports to illustrate its application.

\section{METHODS}

We defined risk as comprising hazards posed by wildlife species to aviation safety and a frequency component, strikes by species. We extracted 69,814 wildlife strike records for 2010-2015 from the FAA's National Wildlife Strike Database (Dolbeer et al. 2016). From that data set, we removed strike records that met $\geq 1$ of the following criteria: strikes with animals other than birds (i.e., mammals or reptiles), strikes that occurred $>457 \mathrm{~m}$ above ground level and thus outside the airport environment (Dolbeer and Begier 2012), strike records based only on bird carcasses found on or near runways (and thus without associated data including damage level or cost of repairs), strikes with unknown species or those attributed only to a species group (e.g., "ducks"), and strikes with species having $<20$ records meeting the criteria listed above. Our final data set contained 11,364 strike records from 79 bird species.

We calculated a relative hazard score (RHS) for the 79 bird species following Dolbeer et al. (2000) and DeVault et al. (2011). Briefly, we calculated RHS by determining the percentage of total strikes for each species that resulted in damage, substantial damage, and negative effect on flight. We then summed those percentages for each species and scaled to a maximum of 100 (Dolbeer et al. 2000, DeVault et al. 2011). As such, RHS is a composite variable that reflects 3 hazard criteria and ranges from 1 to 100 (100 being the most hazardous), and thus provides an index of severity, but not frequency, in the calculation of risk. To estimate frequency of an adverse event (i.e., strike), we used the number of strike records (with any level of damage) in our data set for individual bird species (see below).

We used economic (cost) data from the National Wildlife Strike Database to evaluate 4 risk models. Although costs associated with strikes are not always reported to the FAA when strikes occur (Dolbeer et al. 2016), cost reporting should not be biased across species. Thus, we believe cost data are appropriate for independently validating our risk models. We summed direct (e.g., repairs to aircraft) and indirect (e.g., lost revenue from aircraft downtime) reported costs associated with strikes for each of the 79 species in our data set, and then regressed our risk estimates on those totals (direct plus indirect costs) in 4 models. These models included RHS as the metric of severity and the number of strike records in our data set for a particular species, scaled to 100 (e.g., the most frequently struck species was set to a value of 100 and all other species adjusted accordingly), as the metric of frequency ("Strikes").

Species RHS and strike frequencies represent the most complete, long-term data available relative to defining cause, effect, and frequency components for wildlife strike risk. However, there is no a priori, biologically defined relationship of these data sources to risk. Lacking additional biological data, such as the spatiotemporal relationship between species numbers and aircraft position, or differential behavioral response by species to aircraft approach, our focus was not one of discerning model parsimony relative to a risk metric and reported cost data. Instead, we considered 4 different mathematical relationships (transformations) between the 2 independent variables fit to the independent cost data, given that ecological data are often nonlinear and rarely normally distributed (Gibbs et al. 1991, McKinstry and Anderson 2002). First, we examined a simple linear relationship of species risk, defined by RHS and Strikes. Next, we investigated 3 models involving squares of our original risk components: $\mathrm{RHS}^{2} \times$ Strikes; RHS $\times$ Strikes $^{2}$; and $\mathrm{RHS}^{2} \times$ Strikes $^{2}$. Given that the maximum values for species RHS and Strikes were each 100, based on our scaling, the first calculation of species-specific risk potentially ranged from 0 to 10,000 , the second and third from 0 to $1,000,000$, and the fourth from 0 to $100,000,000$. We note that while strikes and RHS impart biological relevance to the risk metric, there are no data to support a particular a priori mathematical relationship to risk. Thus, the evaluation against independent cost data is critical. We assessed model fit $\left(r^{2}\right)$ of each of the 4 regression models and used the risk estimate from the best-fitting model to generate airportspecific risk estimates.

As noted above, we used calculations including strike records from all United States airports in our data set to evaluate 4 risk models with cost data. However, these national risk scores are limited in applicability given that wildlife communities and management challenges vary greatly across regions and across airports within regions (e.g., Dolbeer and Begier 2012, DeVault et al. 2016). For risk 
Table 1. Number of damaging strikes, total strikes, relative hazard score (RHS), and risk estimates for 79 bird species, selected from strike records reported to the Federal Aviation Administration National Wildlife Strike Database (2010-2015) from across the United States. Risk represents RHS squared (range $=0$ $10,000)$ multiplied by the number of strikes for that species, scaled to 100 , squared (range $=2.21-10,000)$. Total reported cost represents all direct and indirect costs associated with strikes reported for a species. Species are listed in decreasing order of risk.

\begin{tabular}{|c|c|c|c|c|c|c|}
\hline Species & Risk rank & Damaging strikes & Total strikes & RHS & Risk & Total reported cost (\$US) \\
\hline Red-tailed hawk (Buteo jamaicensis) & 1 & 118 & 515 & 44 & $2,780,325$ & $17,660,362$ \\
\hline Canada goose (Branta canadensis) & 2 & 121 & 232 & 87 & $2,233,249$ & $10,872,559$ \\
\hline Turkey vulture (Cathartes aura) & 3 & 89 & 158 & 94 & $1,229,499$ & $4,444,706$ \\
\hline Mourning dove (Zenaida macroura) & 5 & 36 & 1,080 & 9 & 560,248 & 569,698 \\
\hline European starling (Sturnus vulgaris) & 6 & 28 & 698 & 11 & 315,575 & 697,385 \\
\hline Mallard (Anas platyrhynchos) & 7 & 34 & 129 & 57 & 299,799 & $5,617,599$ \\
\hline Bald eagle (Haliaeetus leucocephalus) & 10 & 28 & 64 & 80 & 145,365 & $8,693,343$ \\
\hline Black vulture (Coragyps atratus) & 11 & 30 & 48 & 100 & 127,361 & 564,402 \\
\hline American kestrel (Falco sparverius) & 12 & 5 & 685 & 6 & 99,146 & 5,400 \\
\hline Osprey (Pandion haliaetus) & 13 & 22 & 86 & 42 & 72,175 & 451,143 \\
\hline Barn swallow (Hirundo rustica) & 14 & 6 & 1,345 & 3 & 69,181 & 39,951 \\
\hline Killdeer (Charadrius vociferus) & 15 & 9 & 719 & 5 & 65,127 & 498,060 \\
\hline Great blue heron (Ardea herodias) & 16 & 19 & 70 & 46 & 57,086 & 178,957 \\
\hline Northern pintail (Anas acuta) & 21 & 11 & 40 & 58 & 29,599 & $5,540,520$ \\
\hline Eastern meadowlark (Sturnella magna) & 22 & 5 & 325 & 7 & 24,838 & 556,600 \\
\hline Peregrine falcon (Falco peregrinus) & 23 & 9 & 56 & 35 & 21,023 & 234,550 \\
\hline Snowy owl (Bubo scandiacus) & 24 & 11 & 56 & 34 & 19,759 & $1,450,792$ \\
\hline California gull (Larus californicus) & 25 & 10 & 47 & 38 & 17,420 & 197,420 \\
\hline Horned lark (Eremophila alpestris) & 26 & 2 & 715 & 2 & 16,387 & 72,890 \\
\hline Barn owl (Tyto alba) & 27 & 8 & 162 & 10 & 14,222 & 35,200 \\
\hline Swainson's hawk (Buteo swainsoni) & 28 & 10 & 36 & 44 & 14,159 & 193,227 \\
\hline Wild turkey (Meleagris gallopavo) & 29 & 10 & 24 & 66 & 13,793 & 131,500 \\
\hline Great horned owl (Bubo virginianus) & 30 & 12 & 38 & 39 & 12,217 & 95,500 \\
\hline American crow (Corvus brachyrbynchos) & 31 & 4 & 67 & 16 & 6,080 & 1,292 \\
\hline Glaucous-winged gull (Larus glaucescens) & 32 & 7 & 26 & 36 & 4,751 & 1,000 \\
\hline American robin (Turdus migratorius) & 33 & 6 & 124 & 7 & 4,323 & 103,115 \\
\hline Common myna (Acridotheres tristis) & 43 & 1 & 35 & 14 & 1,276 & 0 \\
\hline Purple martin (Progne subis) & 44 & 2 & 39 & 12 & 1,229 & 79,100 \\
\hline Great egret (Ardea alba) & 45 & 4 & 20 & 23 & 1,158 & 20,500 \\
\hline Lapland longspur (Calcarius lapponicus) & 46 & 1 & 24 & 19 & 1,092 & 0 \\
\hline Savannah sparrow (Passerculus sandwichensis) & 47 & 0 & 72 & 6 & 1,026 & 12,800 \\
\hline Zebra dove (Geopelia striata) & 48 & 0 & 37 & 11 & 836 & 1,000 \\
\hline Western meadowlark (Sturnella neglecta) & 49 & 0 & 189 & 2 & 786 & 285 \\
\hline Tree swallow (Tachycineta bicolor) & 50 & 0 & 258 & 1 & 674 & 500 \\
\hline Cedar waxwing (Bombycilla cedrorum) & 51 & 2 & 55 & 6 & 577 & 3,750 \\
\hline Western sandpiper (Calidris mauri) & 52 & 2 & 43 & 7 & 575 & 34,100 \\
\hline Chimney swift (Chaetura pelagica) & 53 & 1 & 171 & 2 & 565 & 13,800 \\
\hline Western kingbird (Tyrannus verticalis) & 54 & 2 & 47 & 6 & 391 & 1,500 \\
\hline Franklin's gull (Leucophaeus pipixcan) & 55 & 1 & 21 & 12 & 357 & 200 \\
\hline Common grackle (Quiscalus quiscula) & 56 & 1 & 22 & 11 & 342 & 430 \\
\hline House sparrow (Passer domesticus) & 57 & 1 & 40 & 6 & 328 & 2,050 \\
\hline Spotted dove (Streptopelia chinensis) & 58 & 0 & 37 & 6 & 301 & 0 \\
\hline Upland sandpiper (Bartramia longicauda) & 59 & 1 & 24 & 8 & 197 & 0 \\
\hline American golden-plover (Pluvialis dominica) & 60 & 1 & 25 & 7 & 190 & 0 \\
\hline Black-bellied plover (Pluvialis squatarola) & 61 & 2 & 25 & 7 & 190 & 0 \\
\hline Common nighthawk (Chordeiles minor) & 62 & 0 & 60 & 3 & 165 & 0 \\
\hline Burrowing owl (Athene cunicularia) & 63 & 1 & 24 & 7 & 146 & 500 \\
\hline Scissor-tailed flycatcher (Tyrannus forficatus) & 64 & 0 & 46 & 3 & 140 & 550 \\
\hline N. rough-winged swallow (Stelgidopteryx serripennis) & 65 & 1 & 26 & 6 & 139 & 0 \\
\hline Bank swallow (Riparia riparia) & 66 & 0 & 156 & 1 & 139 & $\begin{array}{l}8,014 \\
\quad \text { (Continu }\end{array}$ \\
\hline
\end{tabular}


Table 1. (Continued)

\begin{tabular}{lccccrr}
\hline Species & Risk rank & Damaging strikes & Total strikes & RHS & Risk & Total reported cost (\$US) \\
\hline Brown-headed cowbird (Molothrus ater) & 67 & 0 & 30 & 3 & 41 & 0 \\
Scaly-breasted munia (Lonchura punctulata) & 68 & 0 & 33 & 3 & 38 & 5,000 \\
House finch (Haemorhous mexicanus) & 69 & 0 & 31 & 3 & 36 & 50 \\
American pipit (Anthus rubescens) & 70 & 0 & 60 & 1 & 35 & 0 \\
Gray catbird (Dumetella carolinensis) & 71 & 0 & 21 & 4 & 33 & 33 \\
Semipalmated sandpiper (Calidris pusilla) & 71 & 0 & 21 & 4 & 0 & 5,500 \\
Dark-eyed junco (Junco hyemalis) & 73 & 0 & 23 & 0 & 0 & 0 \\
Eurasian skylark (Alauda arvensis) & 73 & 0 & 23 & 0 & 0 & 0 \\
Lark bunting (Calamospiza melanocorys) & 73 & 0 & 21 & 0 & 0 & 0 \\
Least sandpiper (Calidris minutilla) & 73 & 0 & 34 & 0 & 0 & 0 \\
Song sparrow (Melospiza melodia) & 73 & 0 & 20 & 0 & 0 & 0 \\
White-throated sparrow (Zonotrichia albicollis) & 73 & 0 & 26 & 0 & 0 & 500 \\
Yellow-rumped warbler (Setophaga coronata) & 73 & 0 & 40 & 0 & 0 & 500 \\
\hline
\end{tabular}

estimates to be most useful to biologists and managers, species-level risk estimates should be calculated for individual airports, where sufficient strike data are available (e.g., Soldatini et al. 2010, 2011). Therefore, using the bestfitting risk model as described above, we generated airportspecific risk estimates for the 4 busiest airports in the United States, in terms of takeoffs and landings per year: HartsfieldJackson Atlanta International Airport (ATL), Chicago O'Hare International Airport (ORD), Dallas/Fort Worth International Airport (DFW), and Los Angeles International Airport (LAX; FAA 2017). These 4 airports are each located in a different North American migratory flyway (Olson 2015), and experience $>300,000$ aircraft movements annually (FAA 2017); thus, they serve to illustrate how airport-specific risk estimates might compare across regions.

\section{RESULTS}

Relative hazard scores were qualitatively similar to earlier calculations (Dolbeer et al. 2000; DeVault et al. 2011, 2016), with large-bodied (and to a lesser extent, flocking) birds scoring highest (Table 1). Three of the 79 species achieved the maximum score of 100: black vulture (Coragyps atratus), double-crested cormorant (Phalacrocorax auritus), and sandhill crane (Grus canadensis); 7 small-bodied species had a RHS of 0 (they had no damaging strikes in our data set; Table 1). In terms of strike frequency, 2 species had $>1,000$ strikes in our data set: barn swallow (Hirundo rustica) and mourning dove (Zenaida macroura; Table 1).

The best fitting model of risk to cost data comprised RHS and Strikes multiplied to form a single, transformed independent variable $\left(\mathrm{RHS}^{2}\right.$ and Strikes ${ }^{2}, r^{2}=0.74$; Fig. 1, Table 2). The other 3 models exhibited poorer fit (RHS and Strikes ${ }^{2}, r^{2}=0.34$; RHS ${ }^{2}$ and Strikes, $r^{2}=0.58$; RHS and Strikes, $r^{2}=0.68$ ). Under our best-fitting model, the top species in terms of risk nationwide were red-tailed hawk (Buteo jamaicensis; risk $=2,780,325$ ), Canada goose (Branta canadensis; risk $=2,233,249$ ), turkey vulture (Cathartes aura; risk $=1,229,499)$, rock pigeon (Columba livia; risk $=680,923$ ), and mourning dove (risk $=560,248$; Table 1, Fig. 2). The risk relationship for the top 5 species can be viewed conceptually by plotting risk contours relative to the squared terms included in the model. Most species fall on or near one of the axes (Fig. 3), and those with elevated risk scores are those that are especially high in either $\mathrm{RHS}^{2}$ or Strikes $^{2}$ (e.g., turkey vulture and mourning dove, respectively) or both elements of risk (e.g., red-tailed hawk).

Airport-specific risk estimates for ATL, ORD, DFW, and LAX indicated that red-tailed hawks posed the highest risk at the airport scale for ORD and LAX, as well as the second highest risk at ATL (trailing only European starlings) and the third highest risk at DFW (trailing rock pigeons and mourning doves; Table 3). There was a substantial amount of overlap with the top 5 riskiest species locally across these 4 airports with the exception of LAX, where the second through fifth highest-risk species were not ranked in the top 5 for risk at the other 4 busiest airports.

\section{DISCUSSION}

Based on RHS, the 3 most hazardous species to aviation (black vulture, double-crested cormorant, and sandhill crane) are large, flocking birds. However, RHS alone should not form the basis for wildlife management on airports, because some hazardous species (those most likely to cause aircraft damage or effect on flight when struck) are not encountered

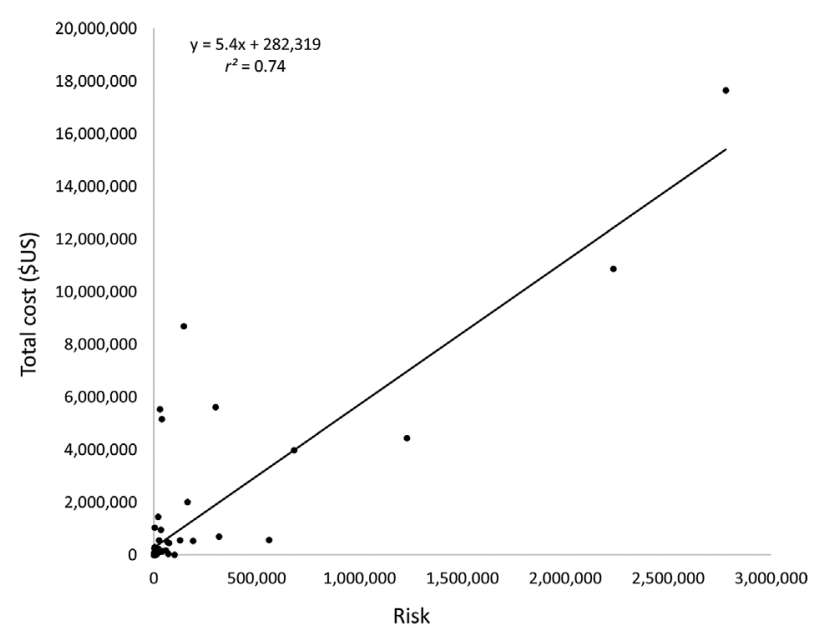

Figure 1. Total cost (direct plus indirect costs associated with strikes reported for a bird species, unadjusted for inflation) versus estimated risk for 79 bird species across the United States. Risk represents relative hazard score squared (range $=0-10,000$ ) multiplied by the number of strikes for that species, scaled to 100 , squared (range $=2.21-10,000)$. 
Table 2. Four candidate models of risk based on relative hazard score (RHS) and the total number of strikes recorded for 79 bird species selected from strike records reported to the Federal Aviation Administration National Wildlife Strike Database (2010-2015) from across the United States. Risk estimates were regressed on economic data (direct plus indirect costs) reported to the Federal Aviation Administration National Wildlife Strike Database for each species. All models were statistically significant at $P<0.001$. The last model (calculating strike risk as $\mathrm{RHS}^{2} \times \mathrm{Strikes}^{2}$ ) was the best fitting model as evaluated by model $r^{2}$ and thus used to generate airport-specific risk estimates.

\begin{tabular}{|c|c|c|c|c|c|}
\hline Risk estimate & $r^{2}$ & Parameter & Coefficient & SE & $P$ \\
\hline \multirow[t]{2}{*}{ RHS $\times$ Strikes } & 0.68 & Risk & $7,291.2$ & 569.4 & 0.14 \\
\hline & & Intercept & $-294,366.5$ & $198,126.4$ & $<0.001$ \\
\hline \multirow[t]{2}{*}{$\mathrm{RHS}^{2} \times$ Strikes } & 0.58 & Risk & 98.7 & 9.7 & $<0.001$ \\
\hline & & Intercept & $175,571.7$ & $213,106.0$ & 0.41 \\
\hline \multirow[t]{2}{*}{ RHS $\times$ Strikes $^{2}$} & 0.34 & Risk & 137.8 & 21.7 & $<0.001$ \\
\hline & & Intercept & $359,865.9$ & $264,381.5$ & 0.18 \\
\hline \multirow{2}{*}{ RHS $^{2} \times$ Strikes $^{2}$} & 0.74 & Risk & 5.4 & 0.4 & 0.09 \\
\hline & & Intercept & $282,319.2$ & $164,084.5$ & $<0.001$ \\
\hline
\end{tabular}

as frequently by aircraft as other, more common species. For example, although black vultures had the highest possible RHS score of 100 , they had the 11th highest risk score, because they are struck less frequently than many of the species ranked higher for overall risk. Wildlife strikes are dynamic instances involving seasonal and diurnal distributions of animals and aircraft movements. For this reason, a probability structure (e.g., risk estimate) is necessary for effective prioritization of management efforts in near time and in projecting future needs. Our best-fitting risk model, a quadratic relationship with both RHS and Strikes, indicated that the red-tailed hawk, Canada goose, turkey vulture, rock pigeon, and mourning dove held the top 5 positions for risk across the USA.

We chose to use strike data as our estimate of frequency in the calculation of risk as opposed to data from bird surveys conducted at airports (e.g., see Soldatini et al. 2010, 2011) because the former is a more direct measure of speciesspecific strike probability. In other words, the number of strikes caused by a particular species in the past is ostensibly the best predictor of future strikes for that species.

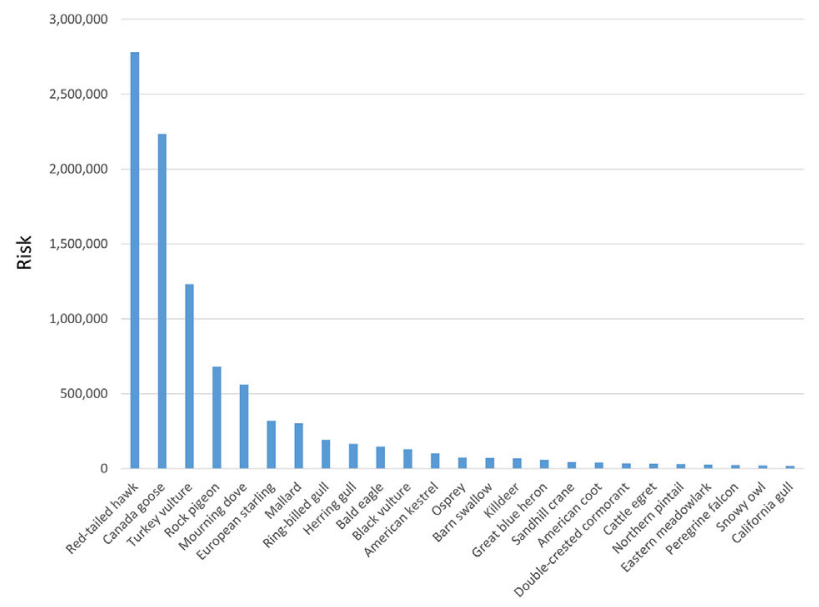

Figure 2. Top-ranked 25 bird species in terms of estimated strike risk with civil aircraft, based on strike records reported to the Federal Aviation Administration National Wildlife Strike Database (2010-2015) from across the United States. Risk represents relative hazard score squared (range $=0$ 10,000 ) multiplied by the number of strikes for that species, scaled to 100 , squared (range $=2.21-10,000)$.
Alternatively, bird surveys at airports can quantify relative use of airport habitats by birds when conducted properly (Blackwell et al. 2013), but generally do not accurately reflect species-specific vulnerability to strikes. For example, some birds using airport habitats spend more time than others in the exact flight paths of aircraft, a behavior that is difficult to discern during standardized airport bird surveys (Schafer et al. 2007). Also, due to physiological and behavioral differences across species, some birds might be less able than others to avoid oncoming, fast-moving vehicles such as aircraft (Møller et al. 2011, Husby and Husby 2014, Santos et al. 2016). For these reasons, strike data should be prioritized for use in risk calculations over bird survey data in situations where adequate strike data are available.

However, risk estimates such as ours provide a foundation for prioritizing wildlife management efforts on an airport that could be refined by survey data, including bias-corrected

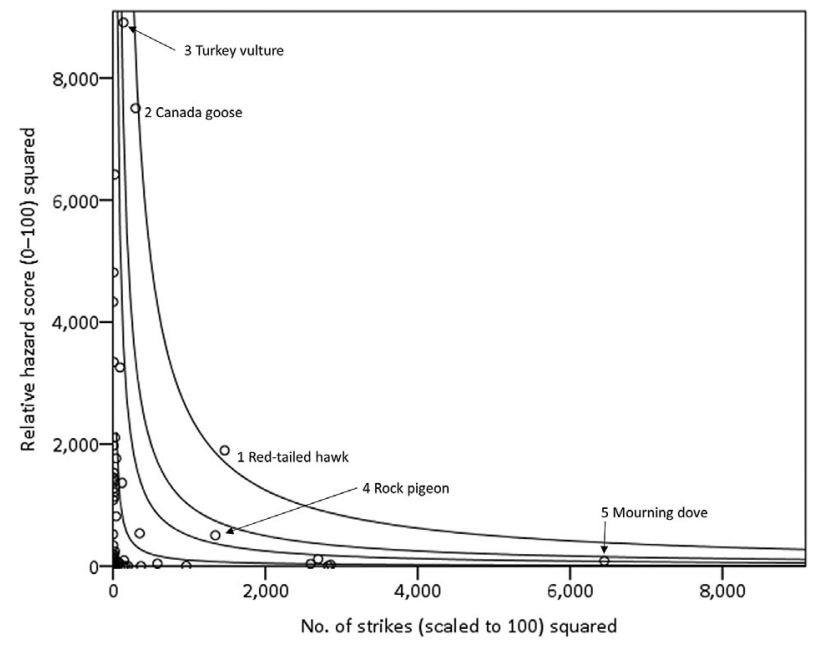

Figure 3. Strike risk expressed as the relationship between the relative hazard score (1-100) squared and the number of strikes (scaled to 100) squared for 79 bird species in the Federal Aviation Administration National Wildlife Strike Database (2010-2015) from across the United States. The top 5 species in terms of overall risk (product of values on $x$ - and $y$-axes) are labeled. Moving outward from the origin, the contour lines represent risk levels of 100,000, 500,000,1,000,000, and 2,500,000 (all species along a line have an equal risk value). 
Table 3. Risk estimates for the 5 riskiest species at each of the 4 busiest airports in the United States as determined by takeoffs and landings. Risk represents relative hazard score squared (range $=0-10,000)$ multiplied by the number of strikes for that species, scaled to 100 , squared $($ range $=2.21-10,000)$.

\begin{tabular}{|c|c|c|c|c|c|c|c|c|c|c|c|c|c|}
\hline \multirow[b]{2}{*}{ Species } & \multirow[b]{2}{*}{$\begin{array}{c}\text { Overall } \\
\text { (U.S.) } \\
\text { risk } \\
\text { rank } \\
\end{array}$} & \multicolumn{3}{|c|}{ ATL (Atlantic Flyway) } & \multicolumn{3}{|c|}{ ORD (Mississippi Flyway) } & \multicolumn{3}{|c|}{ DFW (Central Flyway) } & \multicolumn{3}{|c|}{ LAX (Pacific Flyway) } \\
\hline & & $\begin{array}{c}\text { Local } \\
\text { risk } \\
\text { rank }\end{array}$ & $\begin{array}{l}\text { Damaging } \\
\text { strikes }\end{array}$ & $\begin{array}{l}\text { Local } \\
\text { \% risk }\end{array}$ & $\begin{array}{c}\text { Local } \\
\text { risk } \\
\text { rank }\end{array}$ & $\begin{array}{c}\text { Damaging } \\
\text { strikes }\end{array}$ & $\begin{array}{l}\text { Local } \\
\text { \% risk }\end{array}$ & $\begin{array}{c}\text { Local } \\
\text { risk } \\
\text { rank }\end{array}$ & $\begin{array}{c}\text { Damaging } \\
\text { strikes }\end{array}$ & $\begin{array}{l}\text { Local } \\
\text { \% risk }\end{array}$ & $\begin{array}{c}\text { Local } \\
\text { risk } \\
\text { rank }\end{array}$ & $\begin{array}{c}\text { Damaging } \\
\text { strikes }\end{array}$ & $\begin{array}{l}\text { Local } \\
\text { \% risk }\end{array}$ \\
\hline Red-tailed hawk & 1 & 2 & 1 & 26.15 & 1 & 2 & 50.57 & 3 & 3 & 2.24 & 1 & & 46.75 \\
\hline Canada goose & 2 & & & & 2 & & 17.80 & & & & & & \\
\hline Turkey vulture & 3 & & & & & & & 4 & & 1.88 & & & \\
\hline Rock pigeon & 4 & 4 & 1 & 4.02 & 4 & 1 & 5.84 & 1 & 8 & 78.00 & & & \\
\hline Mourning dove & 5 & 3 & & 4.38 & & & & 2 & 2 & 15.85 & & & \\
\hline $\begin{array}{l}\text { European } \\
\text { starling }\end{array}$ & 6 & 1 & 4 & 58.83 & 3 & 1 & 7.11 & & & & & & \\
\hline Ring-billed gull & 8 & & & & 5 & & 4.18 & & & & & & \\
\hline Black vulture & 11 & 5 & 1 & 2.11 & & & & & & & & & \\
\hline $\begin{array}{c}\text { American } \\
\text { kestrel }\end{array}$ & 12 & & & & & & & & & & 5 & & 3.48 \\
\hline $\begin{array}{l}\text { Great blue } \\
\text { heron }\end{array}$ & 16 & & & & & & & & & & 2 & 2 & 22.71 \\
\hline American coot & 18 & & & & & & & 5 & & 0.45 & 4 & 1 & 8.18 \\
\hline Western gull & 37 & & & & & & & & & & 3 & 2 & 11.90 \\
\hline Totals & & & 7 & 95.48 & & 4 & 85.50 & & 13 & 98.42 & & 5 & 93.01 \\
\hline
\end{tabular}

quantification of species and seasonal relative abundances among landscapes surrounding airports (Blackwell et al. 2013, Andersson et al. 2017). More research is needed on quantitative methods to incorporate bird surveys as supplemental data into risk calculations, or as the sole measure of frequency in cases where adequate strike data are unavailable. Until such methods are developed, biologists should consistently conduct rigorous bird surveys, allowing them to track species the risk model identifies as most problematic at their airports. In this manner, biologists will have data to determine whether their management efforts are effective in reducing strikes involving species that pose the greatest bird strike risk at the airport. In addition, standardized avian surveys, corrected for detection bias, are helpful in determining when and where management on the airport should occur (Blackwell et al. 2013).

Our risk estimates for ATL, ORD, DFW, and LAX highlighted the importance of calculating risk at the local level. For example, red-tailed hawks appear to pose significant risk at all 4 airports, whereas Canada goose, the second riskiest species across the entire United States, was listed in the top 5 riskiest species locally only at ORD. Furthermore, at LAX 4 of the top 5 riskiest species were unique to that airport and outside the top 10 riskiest bird species nationally, suggesting that biologists at that airport face very different wildlife management challenges than those present at other large airports in the United States. Biologists and managers should quantify risk at individual airports to help prioritize wildlife management efforts locally.

Strike risk is dynamic, and risk estimates should ultimately reflect the dynamics of cost (Anderson et al. 2015), wildlife strike probabilities, aircraft movements, and allow for adjustment reflecting wildlife management actions on the airport that could influence future strike risk. Such an approach to risk estimation would move beyond the simple risk model described herein and allow for an informed adjustment of management options based on prior knowledge and realistic strike rates for each species or species group.

\section{MANAGEMENT IMPLICATIONS}

At the airport level, risk of bird strikes should ideally reflect the frequency and severity of strikes caused by various species using airport habitats. We therefore encourage wildlife biologists to adapt our risk metric relative to their airportspecific strike data, and use standardized avian surveys, corrected for detection bias, to further prioritize management efforts at the airport both spatially and temporally. Risk is only a quantitative exercise without this important link to proactive management.

\section{ACKNOWLEDGMENTS}

We thank the U.S. Department of Agriculture, Wildlife Services, Airport Wildlife Hazards Working Group and airport biologists around the United States for their input on estimating strike risk at airports. We thank M. B. Pfeiffer, B. E. Washburn, Associate Editor F. Thompson, and an anonymous reviewer for helpful comments on the manuscript. Much of our research on wildlife hazards to aviation is funded by the Federal Aviation Administration (FAA). Opinions expressed in this study do not necessarily reflect current FAA policy decisions regarding the control of wildlife on or near airports.

\section{LITERATURE CITED}

Allan, J. R. 2002. The costs of bird strikes and bird strike prevention. Pages 147-155 in L. Clark, editor. Proceedings of the National Wildlife Research Center symposium, human conflicts with wildlife: economic considerations. U.S. Department of Agriculture, National Wildlife Research Center, Fort Collins, Colorado, USA.

Allan, J. R. 2006. A heuristic risk assessment technique for birdstrike management at airports. Risk Analysis 26:723-729.

Anderson, A., D. S. Carpenter, M. L. Begier, B. F. Blackwell, T. L. DeVault, and S. A. Shwiff. 2015. Modeling the cost of bird strikes to US civil aircraft. Transportation Research Part D 38:49-58. 
Andersson, K., C. A. Davis, B. F. Blackwell, and J. R. Heinen. 2017. Wetland bird abundance and safety implications for military aircraft operations. Wildlife Society Bulletin 41:424-433.

Blackwell, B. F., T. L. DeVault, E. Fernández-Juricic, and R. A. Dolbeer. 2009. Wildlife collisions with aircraft: a missing component of land-use planning on and near airports? Landscape and Urban Planning 93:1-9.

Blackwell, B. F., P. M. Schmidt, and J. A. Martin. 2013. Avian survey methods for use at airports. Pages 153-165 in T. L. DeVault, B. F. Blackwell, and J. L. Belant, editors. Wildlife in airport environments: preventing animal-aircraft collisions through science-based management. Johns Hopkins University Press, Baltimore, Maryland, USA.

DeFusco, R. P., E. T. Unangst, Jr., T. R. Cooley, and J. M. Landry. 2015. Applying an SMS approach to wildlife hazard management. Airport Cooperative Research Program Report 145, Transportation Research Board of The National Academies. Washington, D.C., USA.

DeVault, T. L., J. L. Belant, B. F. Blackwell, and T. W. Seamans. 2011. Interspecific variation in wildlife hazards to aircraft: implications for airport wildlife management. Wildlife Society Bulletin 35:394-402.

DeVault, T. L., B. F. Blackwell, and J. L. Belant, editors. 2013. Wildlife in airport environments: preventing animal-aircraft collisions through science-based management. Johns Hopkins University Press, Baltimore, Maryland, USA.

DeVault, T. L., B. F. Blackwell, T. W. Seamans, and J. L. Belant. 2016. Identification of off airport interspecific avian hazards to aircraft. Journal of Wildlife Management 80:746-752.

Dolbeer, R. A. 2013. Regulations for wildlife management at airports. Pages 173-174 in T. L. DeVault, B. F. Blackwell, and J. L. Belant, editors. Wildlife in airport environments: preventing animal-aircraft collisions through science-based management. Johns Hopkins University Press, Baltimore, Maryland, USA.

Dolbeer, R. A. 2015. Trends in reporting of wildlife strikes with civil aircraft and in identification of species struck under a primarily voluntary reporting system, 1990-2013. U.S. Department of Transportation, Federal Aviation Administration, Washington, D.C., USA.

Dolbeer, R. A., and M. J. Begier. 2012. Comparison of wildlife data among airports to improve aviation safety. Proceedings of the International Bird Strike Conference 30:25-29.

Dolbeer, R. A., J. R. Weller, A. L. Anderson, and M. J. Begier. 2016. Wildlife strikes to civil aircraft in the United States 1990-2015. U.S. Department of Transportation, Federal Aviation Administration. Serial Report Number 22, Washington, D.C., USA.

Dolbeer, R. A., and S. E. Wright. 2009. Safety management systems: how useful will the FAA National Wildlife Strike Database be? HumanWildlife Conflicts 3:167-178.

Dolbeer, R. A., S. E. Wright, and E. C. Cleary. 2000. Ranking the hazard level of wildlife species to aviation. Wildlife Society Bulletin 28:372-378.

Federal Aviation Administration [FAA]. 2007a. Hazardous wildlife attractants on or near airports. U.S. Department of Transportation, Federal Aviation Administration. Advisory Circular AC 150/5200-33B, Washington, D.C., USA.

Federal Aviation Administration [FAA]. 2007b. Introduction to safety management systems (SMS) for airport operators. U.S. Department of Transportation, Federal Aviation Administration. Advisory Circular AC 150/5200-37, Washington, D.C., USA.

Federal Aviation Administration [FAA]. 2010. Safety management systems for aviation service providers. U.S. Department of Transportation, Federal
Aviation Administration. Advisory Circular AC 120/92A, Washington, D.C., USA.

Federal Aviation Administration [FAA]. 2017. FAA airport data. FAA airport facilities data report. https://www.faa.gov/airports/airport_safety/ airportdata_5010/menu/. Accessed 15 Jan 2017.

Gibbs, J. P., J. R. Longcore, D. G. McAuley, and J. K. Ringelman. 1991. Use of wetland habitats by selected nongame waterbirds in Maine. U.S. Fish and Wildlife Service. Fish and Wildlife Research Publication 9, Washington, D.C., USA

Graham, R. L., C. T. Hunsaker, R. V. O’Neil, and B. L. Jackson. 1991. Ecological risk assessment at the regional scale. Ecological Applications 1:196-206.

Husby, A., and M. Husby. 2014. Interspecific analysis of vehicle avoidance behavior in birds. Behavioral Ecology 25:504-508.

International Civil Aviation Organization [ICAO]. 1991. Bird control and reduction. Airport Services Manual, Doc 9137-AN/898, Part 3. International Civil Aviation Organization, Montreal, Quebec, Canada.

International Civil Aviation Organization [ICAO]. 2002. Land use and environmental control. Airport Planning Manual, Doc 9184AN/902, Part 2. International Civil Aviation Organization, Montreal, Quebec, Canada.

International Civil Aviation Organization [ICAO]. 2004. Convention on international civil aviation (Standards and recommended practices). Annex 14. Aerodromes. Volume I. Aerodrome design and operations. Fourth edition. International Civil Aviation Organization, Montreal, Quebec, Canada.

Martin, J. A., J. L. Belant, T. L. DeVault, L. W. Burger, Jr., B. F. Blackwell, S. K. Riffell, and G. Wang. 2011. Wildlife risk to aviation: a multi-scale issue requires a multi-scale solution. Human-Wildlife Interactions 5:198-203.

McKinstry, M. C., and S. H. Anderson. 2002. Creating wetlands for waterfowl in Wyoming. Ecological Engineering 18:293-304.

Møller, A. P., H. Erritzøe, and J. Erritzøe. 2011. A behavioral ecology approach to traffic accidents: interspecific variation in causes of traffic casualties among birds. Zoological Research 32:115-127.

Olson, S. M. 2015. Pacific flyway data book, 2015. U.S. Department of Interior, Fish and Wildlife Service, Division of Migratory Bird Management, Vancouver, Washington, USA.

Santos, S. M., A. Mira, P. A. Salgueiro, P. Costa, D. Medinas, and P. Beha. 2016. Avian trait-mediated vulnerability to road traffic collisions. Biological Conservation 200:122-130.

Schafer, L. M., B. F. Blackwell, and M. A. Linnell. 2007. Quantifying risk associated with potential bird-aircraft collisions. Pages 56-63 in C. L. Irwin, D. Nelson, and K. P. McDermott, editors. Proceedings of the International Conference on Ecology and Transportation. Center for Transportation and the Environment, North Carolina State University, Raleigh, North Carolina, USA.

Soldatini, C., Y. V. Albores-Barajas, T. Lovato, A. Adriano, P. Torricelli, A. Montemaggiori, C. Corsa, and V. Georgalas. 2011. Wildlife strike risk assessment in several Italian airports: lessons from BRI and a new methodology implementation. PLoS ONE 6:e28920.

Soldatini, C., V. Georgalas, P. Torricelli, and Y. V. Albores-Barajas. 2010. An ecological approach to birdstrike risk analysis. European Journal of Wildlife Research 56:623-632.

Associate Editor: Thompson. 